Merit Research Journal of Food Science and Technology (ISSN: 2354-2527) Vol. 6(1) pp. 001-007, February, 2021

Available online http://www.meritresearchjournals.org/fst/index.htm

Copyright (C) 2021 Merit Research Journals

DOI: $10.5281 /$ zenodo.4586823

Original Research Article

\title{
Water Sources on Organoleptics and Characteristics of Sago Flour
}

\begin{abstract}
Mulono Apriyanto $^{1^{\star}}$, Latarus Fangohoi ${ }^{2}$, Zulharman ${ }^{3}$, Dewi Farah Diba ${ }^{4}$, Yulianti ${ }^{1}$
Abstract

${ }^{1}$ Department Food Science, Isamic University of Indragiri, Tembilahan Hulu Indonesia

${ }^{2}$ Politeknik Pembangunan Pertanian Manokwari Papua Barat

${ }^{3}$ Program Studi PGSD, STKIP Taman Siswa Bima

${ }^{4}$ Sekolah Tinggi Teknologi Kelautan, Makasar Sulawesi Selatan

*Corresponding Author Email: mulonoapriyanto71@gmail.com

The purpose of this study was to determine the best Sago starch from various water sources for the manufacturing process. The variable observed was sensory analysis which included organoleptic observations which included observations of color and aroma. Analysis of physical and chemical properties includes examination of nutritional content and calculation of yield. The research design used was factorial Completely Randomized Design (CRD) with 2 factors and 3 replications. The first factor is river water $(\mathrm{S})$, rainwater $(\mathrm{H})$ and combination of $\mathrm{S}$ and $\mathrm{H}(\mathrm{Y})$, the second factor is heating temperature with 3 levels, namely $130^{\circ} \mathrm{C}, 140^{\circ} \mathrm{C}$, and $150^{\circ} \mathrm{C}$, so that they are combined into 27 experimental units. The results showed that Sago flour using rainwater combined with a heating temperature of 140 ${ }^{\circ} \mathrm{C}$ produced the best treatment. Treatment $\mathrm{H} 140$ produces Sago flour that is in accordance with SNI standards (Indonesian national standards).
\end{abstract}

Keyword: Aroma, Indonesian national standards (SNI), Rainwater, River Water, Sago Flavour

\section{INTRODUCTION}

Potential Indonesia has an area of about 1,128 million hectares or $51.3 \%$ of the 2,201 million hectares of world Sago. Potential productivity of \pm 30 tonnes/ha/year, far exceeding the productivity of rice 16 tonnes/ha/year (Habilla and Cheng, 2015; Jong and Widjono, 2015). According to (Heryani and Silitonga, 2018; Palm et al., 2003), the largest content in Sago is carbohydrates, in $100 \mathrm{~g}$ of dry Sago, there is 94 to $96 \mathrm{~g}$ of carbohydrate that is higher than $80.4 \mathrm{~g}$ of rice, $71.7 \mathrm{~g}$ of corn and potatoes $16.3 \mathrm{~g}$. The total amount of starch storage in a trunk is approximately $300 \mathrm{~kg}$ (dry wt.) in case of Sago palm, the elite species among the starch producing palms (Ehara, 2006).

Processing of Sago by the community is still in the traditional way so that it is less hygienic when viewed from its sanitation and high water content causes its shelf life to be relatively short. Processing of Sago into Sago flour is one of the semi-finished alternatives which aims to extend the shelf life and reduce the use of clean water in the processing (Singhal et al., 2008). Processing of Sago into Sago flour is a viable alternative as reported (Ehara 2009; Jong and Widjono, 2015; Palm et al., 2003; Singhal et al., 2008). Metroxylon palms are distributed in not only freshwater areas but also in brackish water areas near the coast and so are considered to be salt tolerant. Moniharapon (2018) reported that saline water treatment up to EC 6 to $7 \mathrm{mmho} / \mathrm{cm}$ did not affect leaf emergence in Sago palm.

The resulting Sago flour has a fiber content ranging from $1 \%$ to $2 \%$. As a requirement for industrial Sago of $1 \%$ (MS468,1976), starch granules according to SNI 013729-1995 standards, have a pH that meets the standards for food SIRIM MS 470: 1992 amounted to 4.5 to 6.5 and the highest yield was at 2 days immersion $26.40 \%$ and 3 days immersion time of $26.50 \%$ in the use of Bimo CF starter and the highest yield for the use of tape yeast starter was $24.75 \%$ at 1 day immersion time. 


\section{MATERIALS AND METHODS}

\section{Materials}

The materials used in this study include wet Sago starch from Sago processing in the Gaung Anak Serka area. BatangTuaka river water, rainwater and combination of $S$ and $\mathrm{H}$. Analysis materials include biuret reagent, $\mathrm{NaOH}$ (technical), distilled water, $\mathrm{H}_{2} \mathrm{SO}_{4}$ (technical), and $\mathrm{n}$ Hexan.

\section{Methods Research}

The raw material for Sago which is still in the form of logs of 50 to $60 \mathrm{~cm}$ is characterized by a proximate content analysis which aims to determine the proximate content or chemical components of the Sago material used, besides that, the proximate content analysis is also carried out on raw materials that are pressed directly without fermentation using a blender. as a comparison with the fineness of 100 mesh.

The analysis carried out includes analysis of the moisture content of the material, the ash content, the protein content, the fat content, the fiber content, the starch content and the whiteness. After the raw material has been characterized, then the size is reduced by grading

A total of $200 \mathrm{~g}$ of Sago flour which water content is adjusted to $28 \%$ by spraying the three types of water sources. For the amount of water added to achieve a water content of $28 \%$ starch, the following formula is used:

$$
(100 \%-K A 1) \times B p 1=(100 \%-K A 2) \times B p 2
$$

The amount of water the spray uses= BP2-BP1. KA1: Moisture content of starch in initial conditions, KA2: Water content of starch desired, BP1: Weight of starch in initial conditions, BP2: Weight of starch after reaching KA2.

The starch which has been adjusted to $28 \%$ moisture content is then placed in a petri dish then stirred and closed. The starch is allowed to stand in the refrigerator for one night to uniform the moisture content. The pan filled with wet starch is heated in an oven with a heating time of 3 hours at a temperature of $130^{\circ} \mathrm{C}, 140^{\circ} \mathrm{C}$, and $150^{\circ} \mathrm{C}$. The starch is stirred every hour to uniform the heat distribution. After cooling, the modified starch was dried for 4 hours at $50^{\circ} \mathrm{C}$.

\section{Organoleptic Tests}

The observation variables for the organoleptic test analysis included texture, aroma, color, and taste of Sago flour for each treatment, to determine what the panelists liked the most, this test was based on the panelists' scoring of color and aroma. The test used 25 untrained panelists. The assessment is given based on sensory criteria (Apriyanto et al. 2016, 2017).

\section{Physicochemical Analysis}

The physicochemical analysis carried out in this study included physical analysis (viscosity) using the Ostwald method (Ehara, 2009). Chemical analysis includes the calculation of yield (Ariyani et al., 2020), moisture content in the thermogravimetric method (Horwitz and George, 2005), protein content in the Biuret method (Horwitz and George W. Latimer 2005), fat content in the Soxhlet extraction method (Horwitz and George W. Latimer 2005), ash content in the thermogravimetric method (Horwitz and George W. Latimer 2005), reflux method fiber content (Horwitz and George W. Latimer 2005) and carbohydrate content by difference method (Horwitz and George W. Latimer 2005), pH (Horwitz and George W. Latimer 2005).

\section{Research design}

The research design used was factorial Completely Randomized Design (CRD) with 2 factors and 3 replications. The first factor is river water $(S)$, rainwater $(H)$ and combination of $S$ and $H(Y)$, the second factor is heating temperature with 3 levels, namely $130^{\circ} \mathrm{C}, 140^{\circ} \mathrm{C}$, and $150^{\circ} \mathrm{C}$, so that they are combined into 27 experimental units.

\section{Data analysis}

Data analysis in this study was obtained from organoleptic variables, degree of acidity $(\mathrm{pH})$, degree of whiteness, water content analysis, protein content analysis, fat content analysis, and ash content analysis, fiber content analysis. Data were analyzed using analysis of variance (Analysis of Variants). The results which significantly affected the observed variables were continued with Duncan's Multiple Range Test (DMRT) at the $95 \%$ confidence level $(\alpha=0.05)$.

\section{RESULTS AND DISCUSSION}

\section{Organoleptic Test}

Recapitulation of the results of analysis of variance (ANOVA) of Sago starch products using the Heat Moisture Treatment (HMT) method. Combination of three different types of water sources on the organoleptic assessment which includes color, aroma, and texture as 
Table 1. Recapitulation analysis of various Sago starches using the Heat Moisture Treatment method (Forages) The combination of three different types of water sources for organoleptic assessment(color, aroma, and texture), viscosity, yield, and $\mathrm{pH}$.

\begin{tabular}{lcccc}
\hline \multirow{2}{*}{ No } & \multirow{2}{*}{ Observation Variable } & \multicolumn{3}{c}{ Variety analysis } \\
\cline { 3 - 5 } & Organoleptic color & Water sources & HMT & Water sources + HMT \\
\hline 1 & Organoleptic aroma & ${ }^{* *}$ & tn & ${ }^{*}$ \\
\hline 2 & Organoleptic texture & ${ }^{*}$ & tn & ${ }^{*}$ \\
\hline 3 & Viscosity & tn & tn & tn \\
\hline 4 & Rendement & tn & tn & tn \\
\hline 5 & $\mathrm{pH}$ & ${ }^{*}$ & tn & tn \\
\hline 6 & &
\end{tabular}

Note: ${ }^{* *}=$ Very significant effect, tn $=$ not significant effect, ${ }^{*}=$ Has significant effect, HMT $=$ Heat Moisture Treatment

Table 2. Average results of panelists' assessment of the color organoleptic Sago flour combination of water sources and HMT

\begin{tabular}{lcc}
\hline Treatment & Average & Appearance \\
\hline Y130 & $3,60 a \pm 0,17$ & white \\
\hline $\mathrm{S} 130$ & $3,50 \mathrm{ab} \pm 0$ & slightly white \\
\hline $\mathrm{H} 130$ & $3,50 \mathrm{ab} \pm 0$ & white \\
\hline $\mathrm{H} 140$ & $3,43 \mathrm{ab} \pm 0,12$ & white \\
\hline $\mathrm{S} 140$ & $3,37 \mathrm{bc} \pm 0,23$ & slightly white \\
\hline $\mathrm{Y} 140$ & $3,37 \mathrm{bc} \pm 0,23$ & slightly white \\
\hline $\mathrm{S} 150$ & $3,30 \mathrm{ab} \pm 0$ & slightly white \\
\hline $\mathrm{H} 150$ & $3,30 \mathrm{bc} \pm 0$ & slightly white \\
\hline $\mathrm{Y} 150$ & $3,10 \mathrm{c} \pm 0,17$ & slightly white \\
\hline
\end{tabular}

Note: The numbers followed by different letter notations show significant differences based on the DMRT test of 0.05 at the $95 \%$ confidence level. Treatment codes: S (river water), $\mathrm{H}$ (rainwater), $\mathrm{Y}$ (mixture of $\mathrm{H}$ $+\mathrm{S}), 130$ (temperature $130^{\circ} \mathrm{C}$ ), 140 (temperature $140^{\circ} \mathrm{C}$ ) and 150 (temperature $150^{\circ} \mathrm{C}$ ).

shown in Table 1.

Based on the analysis of variance in Table 1, it shows that the organoleptic assessment of the color variable, the aroma variable, has a very significant effect on the treatment of various water sources. The texture variable only had a significant effect on treatment water sources. and HMT, while fermentation. Each $\mathrm{pH}$ has a very significant effect on the treatment of water sources. viscosity and yield did not significantly affect all treatments. Analysis of variance on HMT treatment of all variables had no significant effect. In the combination treatment of water sources and forages, the organoleptic assessment had a significant effect on the variable color and aroma variables.

\section{Color}

Based on the results of the assessment of the organoleptic test on Sago flour with the heat meanstre treatment method combined with different water sources, it is known that the treatment of HMT heating temperature variations shows the results have a very significant effect on the assessment.

\section{Color}

Based on the results of the assessment of the organoleptic test on Sago flour with the heat moisture treatment method combined with different water sources, it is known that the treatment of forage temperature variations showed a very significant effect on the color organoleptic assessment of the treatment of water sources and forages. The average results of the panelists' assessment of the organoleptic color of Sago flour with the heat moisture treatment method combined with different water sources and the results of the DMRT test are presented in Table 2.

Based on the data above, information is obtained that the treatment of different types of microbes has significant impact on the color or whiteness of Sago flour. The variation of heating temperature in Sago flour that has been washed with various water sources at the highest organoleptic assessment is $\mathrm{H} 130$, namely with water sources using rainwater and combination of $S$ and $\mathrm{H}$ and heating forages with a temperature of $130^{\circ} \mathrm{C}$ of 3.60 and the lowest organic assessment is $\mathrm{S} 130$ treatment, namely by river water with a heating temperature of $130^{\circ} \mathrm{C} \mathrm{HMT}$ of 3.10 . 
004 Merit Res. J. Food Sci. Technol.

Table 3. Average results of panelists' assessment of the organoleptic aroma of combined Sago flour and forage sources.

\begin{tabular}{lcc}
\hline Treatment & Average & Appearance \\
\hline $\mathrm{Y} 130$ & $3,50 \mathrm{a} \pm 0$ & smells \\
\hline $\mathrm{S} 130$ & $3,43 \mathrm{ab} \pm 0,21$ & smells \\
\hline $\mathrm{H} 130$ & $3,40 \mathrm{ab} \pm 0,17$ & It smells a little \\
\hline $\mathrm{H} 140$ & $3,37 \mathrm{ab} \pm 0,06$ & It smells a little \\
\hline $\mathrm{S} 140$ & $3,37 \mathrm{ab} \pm 0,06$ & smells \\
\hline $\mathrm{Y} 140$ & $3,33 \mathrm{ab} \pm 0,06$ & smells \\
\hline $\mathrm{S} 150$ & $3,30 \mathrm{bc} \pm 0,10$ & smells \\
\hline $\mathrm{H} 150$ & $3,23 \mathrm{bc} \pm 0,15$ & It smells a little \\
\hline $\mathrm{Y} 150$ & $3,10 \mathrm{c} \pm 0,17$ & smells \\
\hline
\end{tabular}

Note: The numbers followed by different letter notations show significant differences based on the DMRT test of 0.05 at the $95 \%$ confidence level. Treatment codes: $\mathrm{S}$ (river water), $\mathrm{H}$ (rainwater), $\mathrm{Y}$ (mixture of $\mathrm{H}$ $+\mathrm{S}), 130$ (temperature $130^{\circ} \mathrm{C}$ ), 140 (temperature $140^{\circ} \mathrm{C}$ ) and 150 (temperature $150^{\circ} \mathrm{C}$ ).

Decreasing preference of the panelists to the parameter of color or degree of whiteness of Sago flour and heating of the forage temperature occurred in all variations of the treatment. Reduced degree of Sago starch whiteness that occurs due to high heating temperatures in forage modification. This statement is in accordance with the research that has been done by (Ega and Lopulalan 2015), White degree is one of the physical properties that changes in the modification process, the results of observations made show that the higher the heating temperature is carried out, the white degree of the material food will decrease. It can be seen that heating the HMT Sago starch at a temperature of $150^{\circ} \mathrm{C}$ gives a lower whiteness value when compared to a heating temperature of $130^{\circ} \mathrm{C}$.

Aroma

The mean results of panelists assessment of the organoleptic aroma of Sago starch products combined with the HMT method are presented in Table 3.

The results of the organoleptic assessment of the aroma of Sago flour which was a combination of water sources and HMT based on the results of the analysis of variance showed that the treatment of different types of water sources in the processing of Sago flour showed no significant effect on the organoleptic assessment, aroma in each treatment. Based on the data in Table 3, information was obtained that the variations in the type of water and temperature of forage in Sago starch showed significantly different results in the treatment of water sources and the combination of water sources and forages. The treatment of water sources and the combination of water sources and forages obtained Sago starch products on the organoleptic assessment of the highest aroma of the panelists' assessment in the Y130 treatment, namely a mixture of river water and rainwater and heating forages with a temperature of $130^{\circ} \mathrm{C}$ of 3.50 slightly smelly, the lowest was in the $\mathrm{S} 130$ treatment, namely river water and heating forages with a temperature of $130^{\circ} \mathrm{C}$ of 3.10 . The change in the distinctive aroma of Sago flour is thought to be due to the washing process that is carried out several times, this statement is in accordance with the opinion of (Tuahta et al., 2014).

The cause of the loss of distinctive odor is influenced by clean rainwater on Sago starch where lactic acid bacteria hydrolyze starch granules to produce monosaccharides. as a raw material for producing organic acids, especially lactic acid, which will be contained in materials that cause odor changes in MOSAS.

\section{Rendement}

The results of the analysis of the yield of Sago starch resulting from several different treatments and variations in the temperature of the HMT based on the results of the analysis of variance showed that the water source treatment and heating temperature variations for HMT in Sago starch products did not significantly affect the yield in each treatment. The average number of yield of Sago flour through the washing method combined with the HMT method fermented with different water sources is presented in Table 4.

Based on the data in Table 4, it is found that the highest average yield of $Y 130$ treatment is $66.79 \%$, while the control is $58.94 \%$. This shows that the highest yield in Y130 treatment is significantly different from the number of control yields, but not significantly different for each treatment. The decrease in yield value in all treatments was thought to be because the process of adding water increased the water content of Sago flour to $28 \%$ in the forage process. In this process, it is suspected that the incubation process in the refrigerator has not been able to uniform the moisture content in the sample so that the ovening process at forage temperatures, namely $130^{\circ} \mathrm{C}$, $140^{\circ} \mathrm{C}$, and $150^{\circ} \mathrm{C}$, gives gelatinization effect and the starch granules break. Cracked starch granules cause 
Table 4. Average yield of Sago flour combination of water sources and HMT

\begin{tabular}{ll}
\hline Treatment & Average (\%) \\
\hline Y130 & $66,79 \pm 0,02$ \\
\hline $\mathrm{S} 130$ & $66,75 \pm 0,02$ \\
\hline $\mathrm{H} 130$ & $66,76 \pm 0,02$ \\
\hline $\mathrm{H} 140$ & $66,77 \pm 0,02$ \\
\hline $\mathrm{S} 140$ & $66,74 \pm 0,02$ \\
\hline $\mathrm{Y} 140$ & $66,73 \pm 0,02$ \\
\hline $\mathrm{H} 150$ & $66,76 \pm 0,02$ \\
\hline $\mathrm{Y} 150$ & $66,77 \pm 0,02$ \\
\hline
\end{tabular}

Note: The numbers followed by different letter notations show significant differences based on the DMRT test of 0.05 at the $95 \%$ confidence level. Treatment codes: $\mathrm{S}$ (river water), $\mathrm{H}$ (rainwater), Y (mixture of $\mathrm{H}+\mathrm{S}$ ), 130 (temperature $130^{\circ} \mathrm{C}$ ), 140 (temperature $140^{\circ} \mathrm{C}$ ) and 150 (temperature $150^{\circ} \mathrm{C}$ ).

Table 5. Average results of $\mathrm{pH}$ analysis of the combination of water and HMT Sago flour

\begin{tabular}{ll}
\hline Treatment & Average (\%) \\
\hline Y130 & $7,51^{a_{ \pm 0,05}}$ \\
\hline S130 & $7,50^{a_{ \pm 0,04}}$ \\
\hline$H 130$ & $7,47^{a b_{ \pm 0,06}}$ \\
\hline$H 140$ & $7,46^{a b_{ \pm 0.06}}$ \\
\hline S140 & $7,43^{a b_{ \pm 0,03}}$ \\
\hline$Y 140$ & $7,33^{b_{ \pm 0,08}}$ \\
\hline S150 & $6,32^{c_{ \pm 0,18}}$ \\
\hline$H 150$ & $6,28^{c_{ \pm 0,07}}$ \\
\hline$Y 150$ & $5,83 d \pm 0,07$ \\
\hline
\end{tabular}

Note: The numbers followed by different letter notations show significant differences based on the DMRT test of 0.05 at the $95 \%$ confidence level. Treatment codes: $\mathrm{S}$ (river water), $\mathrm{H}$ (rainwater), $\mathrm{Y}$ (mixture of $\mathrm{H}+\mathrm{S}$ ), 130 (temperature $130^{\circ} \mathrm{C}$ ), 140 (temperature $140^{\circ} \mathrm{C}$ ) and 150 (temperature $150^{\circ} \mathrm{C}$ ).

the flour becomes sticky and when dry the flour becomes hard and difficult to mash.

\section{PH analysis}

The results of the analysis of the $\mathrm{pH}$ of Sago flour produced from several treatments and temperature variations for HMT based on the results of analysis of variance showed that the results had a very significant effect on the $\mathrm{pH}$ value in each treatment.

Based on the data in Table 5, it is found that the average $\mathrm{pH}$ of Sago flour for the best treatment is 7.51, while the control is 6.35 . This shows that the $\mathrm{pH}$ of the best treated Sago starch is very significantly different from the control $\mathrm{pH}$, by looking at the data that has been done, the results are very significant. The results of research by Majid (2015) show that with the increase in the amount of acid excreted by LAB due to the accumulation of acid in the substrate, it will increase the acidity of the substrate and increase the accumulation of acid in this substrate can be seen by decreasing the $\mathrm{pH}$ of the substrate (Ehara 2009; Ehara, Matsul, and Naito 2006; Heryani and Silitonga, 2018).

The average $\mathrm{pH}$ value of Sago flour that has been treated in various combination treatments with the HMT method is presented in Table 5.

\section{Best Treatment Chemical Analysis}

The best treatment and control combination of modified Sago flour was based on chemical analysis, namely moisture content, protein content, ash content, fat content, fiber content, and carbohydrate content. The best treatment used in this research is Sago flour with various water sources and heating temperature of forage $140^{\circ} \mathrm{C}$, while the control used is Sago flour with river water (traditionally). Recapitulation of the results of the chemical content analysis of Sago flour products with the best treatment and control of chemical properties including water content, protein content, ash content, fat 
Table 6. Chemical composition of combined Sago starch and HMT

\begin{tabular}{lcccc}
\hline \multirow{2}{*}{ No } & \multirow{2}{*}{ Composition } & \multicolumn{3}{c}{ Total (\%) } \\
\cline { 2 - 5 } & & Control & Y140 & SNI \\
\hline 1 & Water content & 9.57 & 5.88 & Max.13 \\
\hline 2 & Protein content & 4.75 & 4.17 & - \\
\hline 3 & Ash content & 0.09 & 0.12 & Max.0,5 \\
\hline 4 & Fat level & 0.9 & 0.55 & - \\
\hline 5 & Fiber content & 1.5 & 1 & 0,1 \\
\hline 6 & Starch content & 83.1 & 88.28 & - \\
\hline
\end{tabular}

Specification: $\mathrm{Y} 140$ (combined treatment of water source and drying temperature).

content, fiber content and carbohydrate content, as shown in Table 6.

Based on the results of the analysis of variance in Table 6, it shows that the water content of the selected treatment is much lower than the control Sago flour, the main cause of a significant decrease in water content is due to heating the temperature of the forages using high temperatures, namely

$150^{\circ} \mathrm{C}$ for 3 hours and followed by drying for 5 hours. The decrease in protein content occurs in the foraging process, this is due to the presence of damaged protein during high heating, but the decrease in protein content is not too significant because the incubation process has occurred spontaneously fermentation, which is thought to increase the value of the protein content.

The fat content that has decreased when compared to the control is also thought to be caused by high temperatures so that the fat in Sago flour is oxidized, while the decrease in ash and fiber content is thought to be due to the fermentation process carried out, according to Apriyanto et al. (2017) tape yeast consists of mold Rhizopus oryzae, Mucor), yeast (Sacharomyces cerevisiae, Sacharomyces verdomanni, Candida utilis) and bacteria (Pediococcus sp. and Bacillus sp.). from the results of research conducted by Tuahta et al. (2014) that Bacillus sp. Effective in reducing crude fiber content with an incubation time of 2 days. This is in line with the results of this study, the largest decrease in fiber content was up to $1.69 \%$ with 2 days of immersion time. And after 3 days the fiber content increases because the development of mold which consistently increases during the fermentation period can contribute crude fiber through the cell walls. And according to Moniharapon (2018) the generative time of mold is 3 to 6 days.

\section{CONCLUSION}

Sago flour which is produced from a combination of water and heating temperature of forage drying, namely $130^{\circ} \mathrm{C}$, $140 \circ \mathrm{C}$ and $150^{\circ} \mathrm{C}$, results in changes in the physical and chemical characteristics of Sago flour. The water source treatment and the HMT heating combination lowered the temperature viscosity of flour, reduced rancidity and can retain the color of Sago flour. the higher the heating temperature of the forage, the lower the viscosity value and the whiter the Sago starch produced.

\section{REFERENCES}

Apriyanto M, Sutardi EH, Supriyanto (2016). "Fermentation Process Improvement of Cocoa Beans with Addition of Non Fermentation Inoculum of Saccharomyces Cerevisiae, Lactobacillus Lactis, and Acetobacter Aceti." AGRITECH, 36(4): 410-15.

Apriyanto M, Sutardi S, Supriyanto S, Eni H (2017). “Cocoa Beans Dry Fermentation Using Saccharomyces Cerevisiae, Lactobacillus Lactis and Acetobacter Aceti." Agritech 37(3): 302.

Ariyani O, Fatma ZN, Mulono A, Veriani A (2020). "Total of Phenol and Antioxydant Activities of Rice Bran Yoghurt." Jurnal Gizi dan Dietetik Indonesia (Indonesian J. Nutr. Dietetics) 7(2): $37-40$.

Ega, La, and Cynthia Gracia Christina Lopulalan. 2015. "Modifikasi Pati Sagu Dengan Metode Heat Moisture Treatment." Agritekno: Jurnal Teknologi Pertanian 4(2): 33-40.

Ehara, Hiroshi. 2009. "Potency of Sago Palm as Carbohydrate Resource for Strengthening Food Security Program." Indonesian Journal of Agronomy 37(3): 209-19.

Ehara, Hiroshi, Moe MatsuI, and Hitoshi Naito. 2006. "Avoidance Mechanism of Salt Stress in Sago Palm (Metroxylon Sagu Rottb.).” Japanese Journal of Tropical Agriculture 50(1): 3641.

Habilla, C, and L H Cheng. 2015. "Quality of Jelly Candy Made of Acid-Thinned Starch Added with Different Non-Starch Polysaccharides." Journal of Food Research and Technology 3(1): 14-22. www.jakraya.com/journa/jfrt.

Heryani, Susi, and Rhoito Frista Silitonga. 2018. "Penggunaan Tepung Sagu (Metroxylon Sp.) Asal Riau Sebagai Bahan Baku Kukis Cokelat." Warta Industri Hasil Pertanian 34(2): 53.

Horwitz, Wil liam, and Jr George W. Latimer. 2005. AOAC International Official Methods of Analysis of AOAC International. https://www.techstreet.com/standards/official-methods-ofanalysis-of-aoac-international-20th-edition2016?product_id=1937367.

Jong, F S, Widjono, Adi. 2015. "Sagu: Potensi Besar Pertanian Indonesia." Iptek Tanaman Pangan 2(1): 54-65.

Moniharapon, Angcivioletta. 2018. "Pengaruh Konsentrasi Pati Sagu Termodifikasi Pada Pembuatan Permen." Jurnal Penelitian Teknologi Industri 8(1): 51. 
Palm, Sago, Cassava Starch, Corn Starch, and Ioannis S Arvanitoyannis. 2003. "Carbohydrates." In Encyclopedia of Food Sciences and Nutrition (Second Edition).

Singhal, Rekha S. et al. 2008. "Industrial Production, Processing, and Utilization of Sago Palm-Derived Products." Carbohydrate Polymers 72(1): 1-20.
Tuahta, Beltaser, Fajar Restuhad, and Usman Pato. 2014. "Studi Fermentasi untuk Modifikasi Pati Sagu oleh Bakteri Asam Laktat dengan Metode Perendaman.” Jom Faperta 1(2): 127-31. 